\title{
Resource Use Efficiency among Small - Scale Irrigated Maize Producers in Northern Taraba State of Nigeria
}

\author{
B. S. Gani and B.T.Omonona
}

\author{
Department of Agricultural Economics, University of Ibadan, Ibadan, Oyo State, Nigeria
}

KEYWORDS Water. Irrigated Maize Production. Resource Use. Taraba State

\begin{abstract}
Inefficiency in the use of available scarce resources has been the bane on increased food production hence low income among the cream of farmers across the nation. The study examined resource use efficiency (with water as the key variable) in irrigated maize production in the Northern part of Taraba State. The study revealed that water was over-utilized in irrigated maize production in the area of study since it had an MVP of less than unity. Multistage stratified random and purposive random sampling techniques involving six wards and eighteen villages were used to select respondents. One hundred and twenty (120) questionnaires were administered on one hundred (120) irrigated maize growers. Only one hundred and seventeen (117) of the questionnaires were retrieved for analysis. Data were analyzed using descriptive statistics, gross margin and net farm income analyses and production functions. Data were fitted to four functional forms based on the OLS techniques. The Cobb-Douglas (power function) production function gave the best fit. All the co-efficients except those of agro-chemical and education carried the expected positive signs. The specific objectives of the study were to determine resource use efficiency, describe socio-economic characteristics of irrigated maize growers, estimate cost and returns and identify constraints to irrigated maize production among

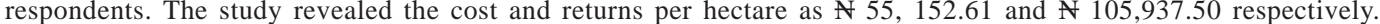
About $73.1 \%$ variability in the dependent variable was accounted for by the independent variables. The result revealed that all the scarce resources were not used efficiently hence not to optimum economic advantage. This was attested to by the high ratios (greater than unity) of MVP/MFC for fertilizer, seeds, labour and land and low ratio (less than unity) for the key variable, water. For optimum resource allocation to water about $233 \%$ decrease in MVP was required while seeds, labour, fertilizer and land required $92.8 \%, 87.1 \%, 71.8 \%$ and $98.7 \%$ increase in MVP respectively. The estimate of elasticity of production summed up to 0.961 meaning decreasing return to scale. Irrigational facilities such as water pumps, sprinklers, pipes and relevant accessories should be made available to farmers to encourage them expand the scale of production thereby boosting increased food production
\end{abstract}

\section{INTRODUCTION}

Agriculture makes use of about $85 \%$ of water consumed in developing countries mainly for irrigational purposes. Although irrigated farming accounts for only about $18 \%$ of the cultivated area in developing world, it produces about $40 \%$ of the value of agricultural output (Cai et al. 2001). As population increases, the demand for agricultural water keeps increasing too hence the need for irrigation becomes more imperative to provide increasing share of food production to meet the growing food demand (Rosegrand and Ringler 1998). The future trajectories of agricultural development in Nigeria are worrisome in view of the inadequate growth in food production and increasing water scarcity. Moreso, inadequate water for agricultural purposes is one of the major causes of poverty in rural area (Maduekwe 2007). This is attributable to poor water resources development and management in Nigeria.

Water resources development in Nigeria can be said to have started in 1908 , when a water- level gauge was created at Jebba for Railway Bridge over the River Niger. In 1914, gauges were laid along the Niger at Baro, Idah, Lokoja and Onitsha and along the Benue at Yola, Ibi and Makurdi (Barau 1991).

The first recorded survey of irrigation potential in Nigeria was in early 1900s, when Colonel Collins, a military engineer, undertook work at the Sokoto-Rima and Zamfara valley systems. The first attempt to impound water, 1918, were later destroyed by the floods in 1922 . Work on flooding and canalization was reported to have been executed on the Shella stream in 1925 and by 1929, 243 ha had been developed for perennial irrigation. Easter (1986) reported that farmers owning land on the scheme could not comply with government requirements for cropping patterns based on cash cropping because they did not find these profitable. At any rate, the scheme was flooded out in 1946. Around then the first irrigation division was established by the Northern Region Ministry of Agriculture. This division was saddled with the responsibility of small-scale irrigation schemes. In 1959, in order 
to develop a network of hydrological stations and organize in-field training services, a hydrological section was established in the irrigation division. A Food and Agriculture Organization (FAO) report commissioned by the Federal government and the study group on Irrigation and Drainage Report accentuated irrigation development in Nigeria. In spite of this giant stride in irrigation development in Nigeria,its performance leaves a lot to be desired.This finds expression in lack of effective harnessing of this key variable with a view to stepping down,to the barest minimum, the devastating effects of drought prevalent in the northern part of the area of study. With drought, the ever increasing human population and subsequent preponderance of demand over supply, the need for increase in the volume of food production towards meeting increase in demand becomes imperative. This will go a long way in guaranteeing food security and improvement in farmers welfare without external reliance on food importation. This is achievable through the development of water(irrigation) and land resources which constitute major integral inputs in agricultural production process and effective harnessing of the surplus and underutilized human labour resources from the increasing population growth available in the country without compromising the sustainability of the industry and environmental resources including water and land resources. To this end, the main questions this research study attempted to ask were what role do socio-economic characteristics play in irrigated maize production?,is irrigated maize production profitable in the study area?,are resources efficiently utilized?, and what are the impediments to increased income in irrigated maize production? The specific objectives were to determine the effects of socioeconomic characteristics on irrigated maize production, to determine cost and return to irrigated maize production, to determine how efficiently or otherwise resources were being utilized in irrigated maize production and finally to identify constraints to effective irrigated maize production in the study area.

A number of studies have been carried out on resource use efficiency in agricultural productivity in Nigeria. Aboki (2007) carried out a comparative analysis of the productivity of improved and local varieties of cassava in selected Local Government Areas of Taraba State. The result revealed the technical efficiency of the farmers with the best and least practice for improved varieties to be 0.9873 and 0.394 respectively. The ones for the local varieties were 0.9705 and 0.2970 for the best and least practiced farmers respectively. Shehu (2007) carried out a comparative economic analysis of small-holder rain-fed and irrigated rice production in selected Local Government Areas of Adamawa State. The result revealed that for rain-fed rice husbandry, land, seeds, hired labour, fertilizer and herbicides were under-utilized while family labour was overutilized. For the irrigated system of rice production land and seeds were optimally utilized while family labour, fertilizer and herbicides were under-utilized and hired labour was over-utilized. Other studies on technical efficiency (Amaza and Olayemi 1999; Amaza 2000; Idumah 2002; Kurkalova and Jensen 2000; Maurice 2004) have shown mean technical efficiencies of $0.69 \%, 70 \%, 89 \%$ ( $82 \%$ in Ukraine), $80 \%$ and $80 \%$ in Nigeria respectively.

\section{MATERIALS AND METHOD}

Multi-stage stratified random and purposive random sampling techniques were used to select irrigated maize growers, based on their relative importance in irrigated maize production from three local government areas. The three local government areas were Ardo-Kola, Jalingo and Lau involving 6 wards and 18 villages from where 120 irrigated maize growers were randomly selected in a ratio proportional to the size of their population.

In all, 120 questionnaires were administered on 120 randomly selected irrigated maize growers but only 117 questionnaires were completed and retrieved for analysis. The data collected were on ages of respondents, their educational attainment, farming experience, production inputs, output, inputs and output prices for 2006 and 2007 cropping seasons.

Gross margin and net farm income analyses (budgeting techniques) were used to estimate cost and returns per hectare and per respondent while the production function analysis was used to determine the resource use efficiency of the inputs used by the farmers. Values were assigned to family labour by obtaining the product of the prevailing wage rate and total mandays of family labour. Additionally, depreciation values of farm tools and implements, (such as hoes, cutlasses and sprayers) rent on land and cost of purchase of land were computed to arrive at the net farm 
revenue per respondent and per hectare. The model considered for estimation of cost and returns per hectare and per respondent is implicitly represented by equation 1 .

$$
\begin{aligned}
& \begin{array}{l}
\text { NFI } \\
\text { Where, }
\end{array} \sum_{i=1}^{n} \mathrm{P}_{\mathrm{yi}} \mathrm{Y}_{\mathrm{i}}-\sum_{j=i}^{m} \mathrm{P}_{\mathrm{xj}} \mathrm{X}_{\mathrm{j}}-\sum_{k=1}^{k} \mathrm{~F}_{\mathrm{k}} \ldots \ldots \ldots \ldots \ldots(1) \\
& \text { NFI }=\text { Net Farm Income } \\
& \mathrm{Y}_{\mathrm{i}} \quad=\quad \text { Gross Output }(\mathrm{Kg}) \\
& \mathrm{P}_{\mathrm{y}}=\text { Unit price of product } \mathrm{Yi} \text { in }(\mathrm{N}) \\
& \mathrm{X}_{\mathrm{j}}^{\mathrm{y}}=\text { Quantity of variable input } \\
& \text { (where } \mathrm{j}=1,2,3 \ldots \mathrm{n} \text { ) } \\
& \mathrm{P}_{\mathrm{xj}} \quad=\quad \text { Price per unit of variable input in }(\mathbb{A}) \\
& \mathrm{F}_{\mathrm{k}}^{\mathrm{x}_{\mathrm{j}}}=\text { Cost of fixed inputs } \mathrm{K} \\
& \text { “ = Summation sign }
\end{aligned}
$$

However, the explicit form of equation 1 used for the computation of average gross margin per respondent and per hectare and for average net revenue per respondent and per hectare is as shown in equation 2.

$$
\begin{aligned}
& \operatorname{AGM}(\mathrm{Ha})^{-1}=\left(\sum_{i=1}^{n} \text { ATRij }\right) \quad\left(\sum_{i=1}^{n} \text { ATVCij }\right) \\
& \overline{\left(\sum_{i=1}^{n} \mathrm{FZ}\right)} \overline{\left(\sum_{i=1}^{n} \mathrm{FZ}\right)} \\
& \operatorname{AGM}(\mathrm{NjK})^{-1}=\left(\sum_{i=1}^{n} \text { ATRij }\right)\left(\sum_{i=1}^{n} \text { ATVCij }\right)
\end{aligned}
$$

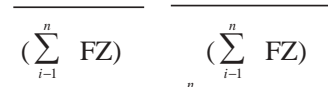

$$
\begin{aligned}
& \operatorname{ANR}(\mathrm{Ha})^{-1}=\operatorname{AGM}(\mathrm{Ha})^{-1}-\left(\sum_{i=1}^{n} \text { ATDep }\right) \\
& \sum_{i=1}^{n}(\mathrm{FZ}) \\
& \operatorname{ANR}(\mathrm{NjK})^{-1}=\operatorname{AGM}(\mathrm{NjK})^{-1}-\left(\sum_{i=1}^{n} \text { ATDep }\right) \\
& \sum_{i=1}^{n}(\mathrm{FZ}) \quad \ldots \ldots \ldots
\end{aligned}
$$

where:

ATDep $=$ Average total depreciation on fixed assets $=$ total fixed cost hectare

$\operatorname{AGM}(\mathrm{Ha})^{-1}=$ Average gross margin per

$\operatorname{AGM}(\mathrm{NjK})^{-1}=$ Average gross margin per respondent

ANR $(\mathrm{Ha})^{-1}=$ Average net revenue per hectare

$\operatorname{ANR}(\mathrm{NjK})^{-1}=$ Average net revenue per respondent

ATRij = Average total revenue accruing to the ith respondent in the jth local

government area.

ATVC $=$ Average total variable cost incurred by the ith respondent in the jth Local Government Area.

$\mathrm{FZ}=$ Farm size of the ith respondent in the jth local government area.
$\mathrm{NjK}=$ Total number of respondents in the $\mathrm{jth}$ local government area.

The general production function used in the study was implicitly of the form represented in equation (6)

$$
\begin{aligned}
& \mathrm{Y}=\mathrm{f}\left(\mathrm{X}_{1}, \mathrm{X}_{2}, \mathrm{X}_{3}, \mathrm{X}_{4}, \mathrm{X}_{5}, \mathrm{X}_{6}, \mathrm{X}_{7}, \mathrm{X}_{8}, \mathrm{X}_{9} \mathrm{U}_{\mathrm{i}}\right) \ldots \ldots \ldots(6) \\
& \text { Where; } \\
& \mathrm{Y}=\text { Maize output }(\mathrm{Kg}) \\
& \mathrm{X}_{1}=\text { Age of irrigated maize grower (years) } \\
& \mathrm{X}_{2}=\text { Water (Ltrs.) } \\
& \mathrm{X}_{3}=\text { Farm size (ha) } \\
& \mathrm{X}_{4}=\text { Seeds }(\mathrm{kg}) \\
& \mathrm{X}_{5}=\text { Fertilizer }(\mathrm{kg}) \\
& \mathrm{X}_{6}=\text { Labour (Mandays) } \\
& \mathrm{X}_{7}=\text { Education (in years) } \\
& \mathrm{X}_{8}=\text { Farming Experience (in years) } \\
& \mathrm{X}_{9}=\text { Agro-chemical (Ltrs.) }
\end{aligned}
$$

Data were fitted to four functional forms using ordinary least square techniques (OLS). The estimated functions were evaluated vis-à-vis the statistical significance of $\mathrm{R}^{2}$ as expressed by the F-ratio, the significance of the coefficients as attested to by the t-values, the plausible signs and magnitude of the coefficients and the magnitude of the standard errors. The a priori expectation of the independent variables was that their coefficients would carry positive signs.

Having tested the effects of all the regressors on the regressand, the Cobb-Douglas production function was chosen as the lead equation, which is implicitly represented by equation (7)

$\mathrm{Y}=\mathrm{ax}_{1}^{\mathrm{b} 1} \mathrm{x}_{2}^{\mathrm{b} 2} \mathrm{x}_{3}^{\mathrm{b} 3} \mathrm{x}_{4}^{\mathrm{b} 4} \mathrm{x}_{5}^{\mathrm{b} 5} \mathrm{x}_{6}^{\mathrm{b} 6} \mathrm{x}_{7}^{\mathrm{b} 7} \mathrm{x}_{8}^{\mathrm{b} 8} \mathrm{x}_{9} \mathrm{~b}^{9} \mathrm{e} \ldots \ldots \ldots$ (7)

The Cobb-Douglas production function in the form expressed above was linearised into a double logarithmic function with a view to getting a form amenable to practical purposes as expressed below.

1. $\operatorname{LnY}=\ln a+b_{1} \ln x_{1+} b_{2} \ln x_{2+} b_{3} \ln x_{3+} b_{4} \ln x_{4+} b_{5} \ln x_{5+} b_{6} \ln x_{6}$

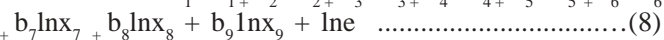
Where,

$\mathrm{Ln}=$ Natural logarithm

$\mathrm{a}=$ constant

$\mathrm{e}=$ error term

$\mathrm{Y}, \mathrm{X}_{1}, \mathrm{X}_{2, \ldots \ldots \ldots . . .} \mathrm{X}_{9}$, are as defined in (6)

\section{Resource Use Efficiency}

The estimated coefficients of the relevant independent variables were used to compute the marginal value products (MVP) and their corresponding marginal factor costs (MFC). The ratio of the MVP to MFC was used to determine the resources efficiency as shown in equation (9).

$r=\quad \underline{\text { MFC }}$ 
where;

$$
\begin{array}{ll}
\mathrm{r}= & \text { Efficiency ratio } \\
\mathrm{MVP}= & \begin{array}{l}
\text { marginal value product of a variable } \\
\text { input. }
\end{array} \\
\mathrm{MFC}= & \begin{array}{l}
\text { Marginal factor cost (Price per unit } \\
\text { input) }
\end{array}
\end{array}
$$

The value of MVP was estimated using the regression coefficient of each input and the price of the output as expressed in equation (10)

$\mathrm{MVP}_{\mathrm{xi}}=\mathrm{MPP}_{\mathrm{xi}} \times \mathrm{P}_{\mathrm{y}}$

Where,

Py $=$ Price of unit output

$\mathrm{MVP}_{\mathrm{xi}}=$ Marginal value product of resource $\mathrm{X}_{\mathrm{i}}$ $(\mathrm{i}=1,2 \ldots \ldots \mathrm{n})$

$\mathrm{MPP}_{\mathrm{xi}}=$ Marginal Physical Product of input $\mathrm{X}$ but

MPPxi $=\frac{\mathrm{dy}}{\mathrm{dxi}}=\frac{\mathrm{bi \overline {y }}}{\overline{\mathrm{X}} \mathrm{i}}$

where;

MPPxi is as defined above,

bi $=$ The estimated regression coefficient of input $\mathrm{Xi}$

$\overline{\mathrm{X}} \mathrm{i}=$ Arithmetic mean value of the input being considered

$\overline{\mathrm{X}}_{\mathrm{i}}=$ Arithmetic mean value of output. (Rahman and Lawal 2003)

The prevailing market price of inputs or depreciation on durable assets was used as the marginal factor cost (MFC) since the farmers were assumed to be operating under purely competitive inputs markets.

On the basis of the economic theory, a firm maximizes profits with respect to resource use when the ratio of the marginal return to opportunity cost is one. The values were interpreted thus;

a) if $r<1$, it means the resource in question was over utilized hence decreasing the quantity used of that resource increases profit.

b) If $r>1$, it shows that the resource was being under utilized and increasing the rate of use will raise profit level.

c) If $\mathrm{r}=1$ it means resource was being efficiently utilized.

The relative percentage change in MVP of each resource required so as to obtain optimal resource allocation, that is $r=1$ or $\mathrm{MVP}=\mathrm{MFC}$, was estimated using equation 12 below:

$\mathrm{D}=\left(1-\frac{\text { MFC }}{\mathrm{MVP}}\right) \times 100=\left(1-\mathrm{r}^{-1}\right) \times 100=$

$$
\left(\frac{1}{1}-\frac{1}{r}\right) \times 100
$$

where:

$\mathrm{D}=$ absolute value of percentage change in MVP of each resource (Mijindadi 1980)

Table 2 reveals that 10 irrigated maize growers

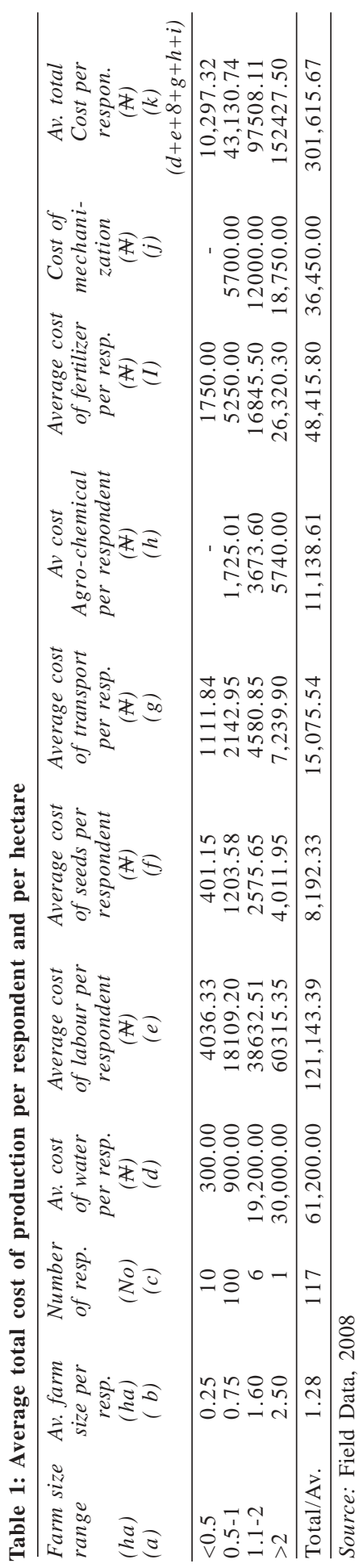


who had less than 0.5 ha earned N17, 109.38 per irrigated maize grower and $\mathrm{N} 68,437.52$ as average gross revenue per hectare. About 100 of them who cultivated pieces of land within the range of 0.5 1ha earned average gross revenue of N51,328 per respondent and average gross revenue of N5,132,812.5 from 75 hectares. The average yield per hectare $(10.95 \mathrm{bags}$ of $100 \mathrm{~kg}$ size each) was multiplied by the average price per $100 \mathrm{~kg}$ bag (N6250) which was multiplied by the total hecatare of (75ha) to arrive at gross revenue of N5,132,812.50 for all the 100 farmers involved in the cultivation. This amount was divided among the 100 farmers to arrived at N51,328.13 as average gross revenue per irrigated maize farmer. Correspondingly, to get the average gross revenue per hectare the gross revenue $5,132,812.5$ (i.e. $51,328.13 \times 100$ ) was divided by the total hectare of 75 ha to get N68,437,52. as average gross return per hectare.

Estimated Depreciation Cost Per Respondent and Per Hectare.

Depreciation on farm tools and implements owned by irrigated maize farmers was computed to aid in computing net farm income using equation (13) below;

$$
\mathrm{D}=\frac{\mathrm{P}-\mathrm{S}}{\mathrm{N}}
$$

where;

$\mathrm{D}=$ Depreciation value in $\mathrm{N}$

$\mathrm{P}=$ cost of implement or tool
$\mathrm{S}=$ salvage value of implement or tool in $\mathrm{A}=$ $10 \%$ of its original cost.

$\mathrm{N}=$ useful life of tool or implement in years

On the basis of the foregoing, table 3 shows the total depreciation of tools and implements of 10 irrigated maize growers cultivating on the average 0.25 ha each computed to be 715.50 which when divided by 10 respondents gave $\$ 715.50$ as average total per respondent. To arrive at the total average depreciation per hectare, the total average depreciation was divided by the total size of the land cultivated by the 10 irrigated maize farmers as $\mathrm{N} 2,862.00$.

\section{Estimated Production Function and Resource Use Efficiency}

The estimated production function was given by equation .....................(18)

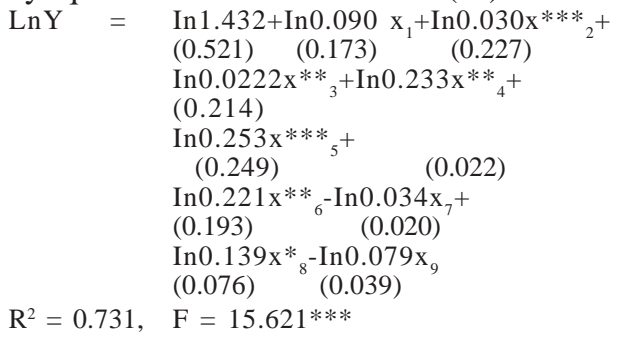

Values in parentheses represent standard errors.

Table 2: Average gross revenue per respondent and per hectare

\begin{tabular}{|c|c|c|c|}
\hline $\begin{array}{l}\text { Irrigated maize } \\
\text { Farm size } \\
\text { Range(ha) } \\
\text { (a) }\end{array}$ & $\begin{array}{c}\text { Average farm } \\
\text { size (ha) } \\
\text { (No.) } \\
\text { (b) }\end{array}$ & $\begin{array}{l}\text { No. of } \\
\text { respondents } \\
\text { (c) }\end{array}$ & $\begin{array}{l}\text { Average gross } \\
\text { revenue per } \\
\text { respondent (A) } \\
\text { (d) }\end{array}$ \\
\hline $\begin{array}{l}<0.5 \\
\end{array}$ & 0.25 & 10 & $17,109.50$ \\
\hline $0.5-1$ & 0.75 & 100 & $51,328.13$ \\
\hline $1.1-2$ & 1.60 & 6 & 109500 \\
\hline$>2$ & 2.5 & 1 & $171,093.75$ \\
\hline Total & 1.28 & 117 & $349,031.26$ \\
\hline
\end{tabular}

Source: Field data, 2008.

Table 3: Average total depreciation in farm tools and implements per respondent and per hectare.

\begin{tabular}{|c|c|c|c|}
\hline $\begin{array}{l}\text { Farm size } \\
\text { Range(ha) } \\
\text { (a) }\end{array}$ & $\begin{array}{c}\text { Average farm } \\
\text { size (ha) } \\
\text { (No.) } \\
\text { (b) }\end{array}$ & $\begin{array}{l}\text { No. of } \\
\text { respondents } \\
\text { (c) }\end{array}$ & $\begin{array}{l}\text { Average total } \\
\text { depreciation per } \\
\text { respondents (N) } \\
\text { (d) }\end{array}$ \\
\hline $\begin{array}{l}<0.5 \\
0.5-1 \\
1.1-2 \\
>2 \\
\end{array}$ & $\begin{array}{l}0.25 \\
0.75 \\
1.60 \\
2.5 \\
\end{array}$ & $\begin{array}{r}10 \\
100 \\
6 \\
1 \\
\end{array}$ & $\begin{array}{r}715.50 \\
915.30 \\
3375.00 \\
5550.00 \\
\end{array}$ \\
\hline Total & 1.28 & 117 & $10,555.80$ \\
\hline
\end{tabular}

Source: Field data, 2008 
Table 4: Average gross margin per respondent and per hactare

\begin{tabular}{lccc}
\hline $\begin{array}{l}\text { Farm size } \\
\text { Range (ha) }\end{array}$ & $\begin{array}{c}\text { Average farm } \\
\text { size of respondent } \\
(\text { ha })\end{array}$ & $\begin{array}{c}\text { No. of } \\
\text { respondents } \\
(\text { No. })\end{array}$ & $\begin{array}{c}\text { Average gross } \\
\text { margin per } \\
\text { respondents (A) } \\
(\text { a })\end{array}$ \\
\hline$<0.5$ & $(\mathrm{~b})$ & $(\mathrm{c})$ & 6812.18 \\
$0.5-1$ & 0.25 & 10 & $8,197.39$ \\
$1.1-2$ & 0.75 & 100 & $11,991.89$ \\
$>2$ & 1.60 & 1 & $18,666.25$ \\
\hline Total & 2.5 & 117 & $45,667.59$
\end{tabular}

Source: Field data, 2008

$\mathrm{d}$ in table $2-\mathrm{K}$ in table $1=\mathrm{d}$ in table 4

Table 5: Average net revenue per respondent and per hectare

\begin{tabular}{|c|c|c|c|c|c|}
\hline $\begin{array}{l}\text { Farm size } \\
\text { Range(ha) } \\
\text { (a) }\end{array}$ & $\begin{array}{l}\text { Average } \\
\text { farm size } \\
\quad \text { (ha) } \\
\text { (b) }\end{array}$ & $\begin{array}{l}\text { No. of } \\
\text { respondents } \\
\text { (No.) } \\
\text { (c) }\end{array}$ & $\begin{array}{l}\text { Average gross } \\
\text { margin per } \\
\text { respondents (A) } \\
(d)\end{array}$ & $\begin{array}{c}\text { Av. Tota } \\
\text { fixed cost } \\
\text { per resp. (A) } \\
(e)\end{array}$ & $\begin{array}{c}\text { Av net } \\
\text { revenue } \\
\text { per resp. (A) } \\
(f)\end{array}$ \\
\hline $\begin{array}{l}<0.5 \\
0.5-1 \\
1.1-2 \\
>2\end{array}$ & $\begin{array}{l}0.25 \\
0.75 \\
1.60 \\
2.5 \\
\end{array}$ & $\begin{array}{r}10 \\
100 \\
6 \\
1 \\
\end{array}$ & $\begin{array}{r}6812.18 \\
8,197.39 \\
11,991.89 \\
18,666.25 \\
\end{array}$ & $\begin{array}{r}715.50 \\
915.30 \\
2375.00 \\
5550.00 \\
\end{array}$ & $\begin{array}{r}6,096.68 \\
7282.09 \\
9,616.89 \\
13,116.25 \\
\end{array}$ \\
\hline Total & 1.28 & 117 & $45,667.59$ & 9555.8 & 36111.14 \\
\hline
\end{tabular}

Source: Field data, 2008

$\mathrm{d}$ in table 4 (i.e. $\mathrm{d}$ in table 5 ) $-\mathrm{d}$ in table $3=\mathrm{f}$ in table 5

$* * *$ denotes significance at $1 \%$ level

$* *$ denotes significance at $5 \%$ level

* denotes significance at $10 \%$ level

Water the key variable that informed this study carried a positive sign and was significant at $1 \%$. Additionally, all other variables, except those of education and agro-chemicals, carried positive signs in consonance with the a priori expectation. This implies that a unit increase in the quantity of each of such inputs will lead to a unit increase in output ceteris peribus.

Table 6 reveals that comparism of the ratio of MVP to MFC shows resulting ratios to be greater than unity for seeds, labour, fertilizer and farmland indicating that such inputs were underutilized.

For our key variable, water, comparison of the ratio of MVP to MFC revealed a resulting ratio to be less than unity implying that water was overutilized. In both cases all the inputs were not utilized to optimum economic advantage. There is the need for adjustment in the marginal value product of all the inputs to ensure optimal use.

Table 7 shows the percentage adjustment in marginal value products for optimum utilization of inputs. Optimum utilization of inputs requires that marginal value product be equal to inputs unit price, that is marginal factor cost $(\mathrm{MVP}=$ MFC).

\section{CONCLUSION}

Water, our key variable, and other variables in the study area were found not to be efficiently utilized hence not to optimum economic advantage. It, therefore, follows that increased food production will be negatively affected. This has far reaching implication for food production. These findings will serve as a bench-mark for a

Table 6: Estimated resource use efficiency in irrigated maize production in northern Taraba state.

\begin{tabular}{|c|c|c|c|c|c|c|}
\hline $\begin{array}{l}\text { Farm } \\
\text { Input }\end{array}$ & $\begin{array}{c}\text { Production } \\
\text { elasticity }\end{array}$ & $M P P$ & Py & $M V P$ & $M F C$ & $M V P / M F C$ \\
\hline Water & 0.030 & 0.00004 & 62.50 & 0.003 & 0.01 & 0.30 \\
\hline Seeds & 0.233 & 14.08 & 62.50 & 880 & 64.01 & 13.75 \\
\hline Labour & 0.221 & 20.48 & 62.50 & 1280 & 165.33 & 7.74 \\
\hline Fertilizer & 0.253 & 1.99 & 62.50 & 124.36 & 35.00 & 3.55 \\
\hline Land & 0.222 & 2560.05 & 62.50 & $160,003.13$ & 2000.00 & 80.00 \\
\hline
\end{tabular}

Source: Field data, 2008 
Table 7: Required adjustment in marginal value product (MVP) (in percentage) for optimal resource allocation of variable inputs.

\begin{tabular}{llc}
\hline $\begin{array}{l}\text { S. } \\
\text { No. }\end{array}$ & Variable input & $\begin{array}{c}\text { Percentage adjustment } \\
\text { required }\end{array}$ \\
\hline 1. & Water & 233 \\
2. & Seeds & 92.8 \\
3. & Labour & 87.1 \\
4. & Fertilizer & 71.8 \\
5. & Land & 98.7 \\
\hline
\end{tabular}

Source: Field data, 2008

grassroot agricultural planning in the state. It is expected that irrigated maize growers, government agricultural agencies and related bodies such as agricultural companies will effectively harness these findings amidst advances in agricultural technology in particular and sustainable agricultural development in general.

\section{REFERENCES}

Aboki Edon 2007. Comparative Analysis of the Productivity of Improved and Local Cassava Varieties in Nigeria. M. Sc. Thesis, Unpublished, Yola: Federal University of Technology Yola.

Amaza PS, Olayemi JK 1999. An investigation of technical inefficiency of production of farmers under the National Directorate of Employment in Ondo State. Applied Economics Letters, Routledge, 6: 111114.

Amaza PS 2000. Resource Use Efficiency in Food Crop Production in Gombe State. Ph.D Thesis, Unpublished, Ibadan: University of Ibadan.

Barau AD 1991. Efficiency of resource use under large scale irrigation farming in Nigeria. A Technical paper submitted as part of the Ford Foundation Inc. Report. Ahmadu Bello University Zaria, August 27 to 29,1991
Cai X, Ringler C, Rosegrant M 2001. Does efficiency of water management matter? Physical and economic efficiency of water use in the river basin, Environment and Production Technology Division. Discussion paper presented at International Food Policy Research Institute Washington DC, USA, August 2 to 5, 2001.

Easter KW 1986. Irrigation Investment Technology and Management Strategies for Development. Westview, (in press).

Idumah FO 2002. Land Productivity Differentials Resource use Efficiency by Food Crops Farmers in Niger Delta Area of Nigeria. M. Sc. Thesis, Unpublished, Ibadan: University of Ibadan.

Kurkalova LA, Jensen HHSC 2000. Technical efficiency of grain production. Working Paper, Centre for Agriculture and Rural Development . Iowa State University, Ames. July 14 to 16, 2000.

Maduekwe IM 2007. Water and infrastructure as critical challenges for agric and rural development. Proceedings of $21^{\text {st }}$ Annual National Conference of Farm Management Association of Nigeria, Ayetoro, Ogun state. March 5 to 82007.

Maurice DC 2004. Resource Productivity in Cereal Crops Production Among Fadama Farmers in Adamawa State. M. Sc. Thesis, Unpublished, Maiduguri: University of Maiduguri.

Mijindadi NB 1980. Production Efficiency on Farms in Northern Nigeria. Ph. D Thesis, Unpublished, Cornell: University of Cornell.

Rahman SA, Lawal AB 2003. Economic analysis of maize based cropping systems in Giwa Local Government Area of Kaduna State. ASSET Report Series No. 3, Nigeria.

Rosegrant MW, Ringler C 1998. Impact on food security and rural dev. of transferring water out of agriculture; Water Policy 6: 567-586.

Shehu JF 2007. Comparative Economic Analysis of Small-holder Rain-fed and Irrigated Rice Production in Selected Local Government Areas of Adamawa State. M. Sc. Thesis, Unpublished, Yola: Federal University of Technology Yola. 